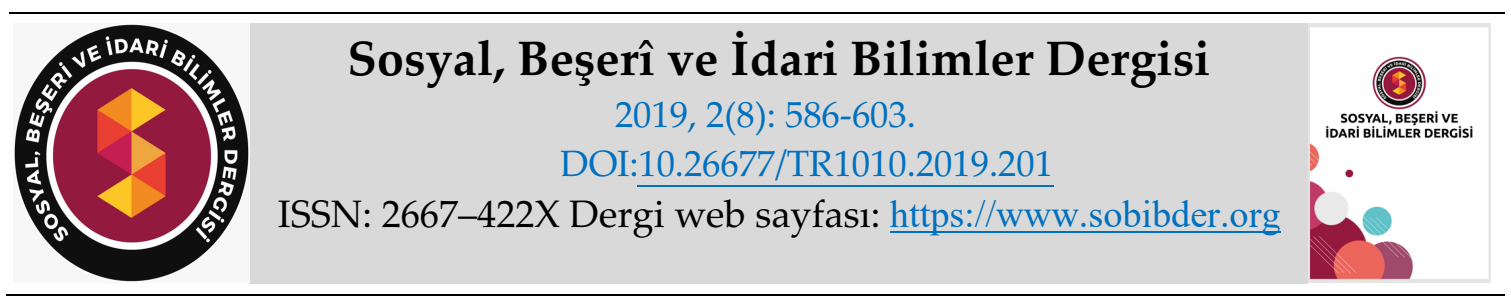

\title{
ARAȘTIRMA MAKALESI
}

\section{Instagramdaki Sosyal Medya Fenomenlerinin Tüketicilerin Satın Alma Davranışlarına Etkisi}

Doç. Dr. Murat TOKSARI, Niğde Ömer Halisdemir Üniversitesi, İ̈BF İşletme Bölümü, Niğde, eposta:mtoksari@gmail.com

ORCID: https://orcid.org/0000-0001-9021-2274

Mehmet MÜRÜTSOY, Doktora Öğrencisi, Niğde Ömer Halisdemir Üniversitesi Sosyal Bilimler Enstitüsü, Niğde, e-posta: m.murutsoy@ohu.edu.tr

ORCID: https://orcid.org/0000-0002-0942-3814

Öz

Günümüz dünyasında işletmeler arasındaki rekabetin her geçen gün artması, işletmeleri pazarlama iletişim aktivitelerinde daha farklı ve etkili yöntemler kullanmaya mecbur bırakmaktadır. Özellikle de çok fazla reklam yığını arasından sıyrılarak, tüketicilerin dikkatini çekebilmek giderek güç bir hale gelmiştir. Bu güçlügü aşabilmek için reklamlara karşı tüketicilerin dikkatini çekebilmek ve bu dikkati sürdürebilmek için daha etkili araçların kullanılması gerektirmektedir. Ürünlerin tanıtımında sosyal medya fenomenlerinin kullanılması bu yöntemlerden birisidir. Bu çalışmada, sosyal medya aracı olan instagram vasitasıyla ürünlerin tanıtımı yapan sosyal medya fenomenlerinin tüketicilerin satın alma davranışları üzerindeki etkisi ortaya çıkarılmaya çalışılmıştır. Bu etkiyi ölçmek için Niğde Ömer Halisdemir Üniversitesi İ.İ.B.F. öğrencilerine anket uygulanarak veriler toplanmış ve elde edilen veriler SPSS paket programlarından faydalanılarak istatistiki açıdan analiz edilmiştir. Araştırma sonuçlarına göre tüketicilerin satın alma kararları sosyal fenomenlerin bir ürüne ilişkin verdiği tavsiyelerden etkilenmektedir

Anahtar Kelimeler: Reklam, Ünlüler, Sosyal Medya Fenomenleri, Instagram.

Makale Gönderme Tarihi: 14.05 .2019

Makale Kabul Tarihi: 28.08.2019

\section{Önerilen Atıf:}

Toksarı, M. ve Mürütsoy, M. (2019). Instagramdaki Sosyal Medya Fenomenlerinin Tüketicilerin Satın Alma Davranışlarına Etkisi, Sosyal, Beşeri ve İdari Bilimler Dergisi, 2(8): 586-603.

(C) 2019 Sosyal, Beşerî ve İdari Bilimler Dergisi. 


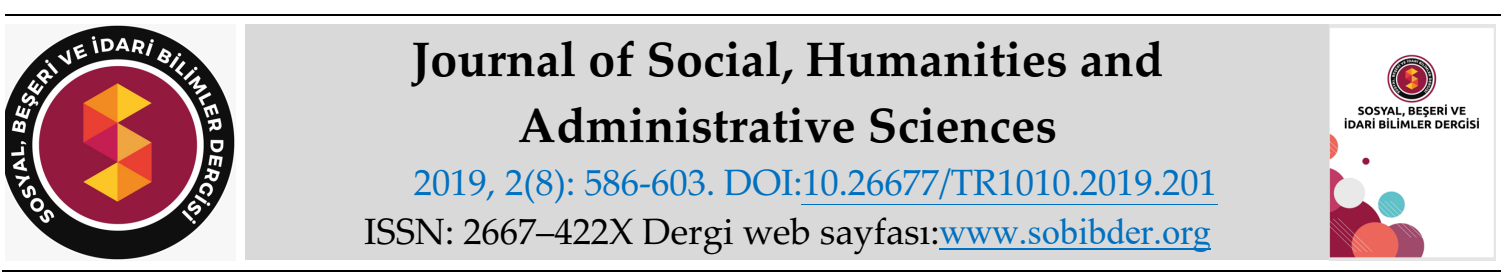

\title{
$\underline{\text { RESEARCH PAPER }}$
}

\section{The Influence of Social Media Influencers on Instagram on Consumers' Purchasing Attitudes}

Associate Prof. Dr. Murat TOKSARI, Niğde Ömer Halisdemir University, Faculty of Economics and Administrative Sciences, Niğde, e-mail:mtoksari@gmail.com

ORCID: https://orcid.org/0000-0001-9021-2274

Mehmet MÜRÜTSOY, Ph.D Student, Niğde Ömer Halisdemir, University Social Sciences Institute, Niğde, e-mail: m.murutsoy@ohu.edu.tr

ORCID: https://orcid.org/0000-0002-0942-3814

\begin{abstract}
The increase in competition among companies day by day in today's world forces them to use more different and effective ways in activities of marketing communication. Especially, it has been difficult to attract consumers' attention to their advertisements from the mass of other ones. It necessary to use more effective means to attract consumers' attention to the advertisements and maintain this attention, so they can handle with this difficulty. Endorsement of social media influencers to promote products is one of these means used by companies. In this study, we try to reveal the influence of social media influencers, who promote products via the social networking site Instagram, on consumers' purchasing attitudes. We have provided data to measure this influence by conducting a questionnaire on the students at the Faculty of Economics and Administrative Sciences in Niğde Ömer Halisdemir University and we analyzed this data statically by using the SPSS packet programs. According to the results of the research, consumers' purchasing decisions are influenced by the recommendations of social phenomena on any product.
\end{abstract}

Keywords: Advertisement, Celebrity, Social Media Influencers, Instagram.

Received: 14.05 .2019

Accepted: 28.08.2019

\section{Suggested Citation:}

Toksarl, M. and Mürütsoy, M. (2019). The Influence of Social Media Influencers on Instagram on Consumers' Purchasing Attitudes, Journal of Social, Humanities and Administrative Sciences, 2(8): 586-603.

(c) 2019 Sosyal, Beşerî ve İdari Bilimler Dergisi. 


\section{Gíriş}

Pazarlama iletişimi perspektifinden bakıldığında pazarlama iletişimi aktiviteleri, ürün tasarımı, markalama, paketleme, fiyatlama ve dağıtım kararları gibi tüketicilerin zihninde pozitif etkiler oluşturmaya çalışan pazarlama karmasının diğer elemanlarını desteklemektedir (Erdogan, 1999:291). Özellikle günümüz dünyasında rekabetin yoğunlaşmasıyla birlikte pazarlama iletişimi aktivitelerinde sosyal medya fenomenlerinin kullanılması tüketicilere ulaşılmasında yeni ve farklı bir strateji olarak ortaya çıkmıştır. Bu perspektifte sosyal medya fenomeni kavramı, sosyal medyayı kendi kitlesini oluşturmak için kullanan ve alışılmış yolla ünlü olmayan kişiler olarak ifade edilmektedir (Clarewells, 2014). Instagram gibi bir sosyal medya aracılığ1 ile sosyal medya fenomenleri geniş kitlelere ulaşabilmektedirler (Marwick, 2015). Geleneksel ünlülerden daha az maliyetli ve daha kolay erişilebilir olması, hedef kitlenin dikkat ve ilgisini çekerek satın alma karar sürecinde farkındalık oluşturması ve satın alma karar sürecinde tüketici üzerinde doğrudan etkiye sahip olması gibi özelliklerinden dolayı işletmelerin ürün ve hizmetlerinin tanitımında sosyal medya fenomeni kullanmayı tercih ettikleri tespit edilmiştir (Brown ve Fiorella, 2013).

$\mathrm{Bu}$ çalışmanın amacı da Instagram vasıtasıyla sosyal medya fenomenlerinin tüketicilerin satın alma davranışları üzerine etkisini belirlemeye yönelik olmuştur. Bu amaçtan yola çıarak ünlü, sosyal medya fenomeni kavramları ve Instagram reklamlarında sosyal medya fenomeni kullanımı incelenmiş ve ardından sosyal medya fenomenlerinin tüketicilerin satın alma davranışları üzerindeki etkisi ölçülmeye çalışılmıştır. Bu etkiyi ölçmek için Niğde Ömer Halisdemir Üniversitesi İktisadi ve İdari Bilimler Fakültesi öğrencilerine yönelik veri toplama yöntemlerinden anket çalışması yapılmak suretiyle veriler toplanmış ve elde edilen veriler SPSS paket programından faydalanılarak istatistiki açıdan analiz edilmiştir.

\section{ÜNLÜLER}

Marka savaşlarının yaşandığı günümüz dünyasında tüketicilerin istek ve ihtiyaçlarını belirleyerek bu istek ve ihtiyaçlara göre inovatif ürün üretme çabaları işletmelere rekabet avantajı kazanmalarında pozitif katkı sağlamıştır. Bu kapsamda farklılık oluşturmak isteyen işletmelerin ürün ve hizmetlerini tanıtırken kullanmış oldukları ünlüler pazarlama iletişimi stratejisinin önemli araçlarından birisi olarak ortaya çıkmıştır (Erdogan, 1999:291). Ünlüler, rekabet ve çekicilikten daha fazla şey ifade etmektedirler (McCracken, 1989). Reklamlarda ünlü kullanmak, reklamlara karşı daha fazla ilgi ve dikkatin çekilmesine, reklam mesajlarının akılda kalıcı hale gelmesine ve markalaşmanın sağlanmasına yönelik çok büyük avantajlar sağlamaktadır (Misra ve Beatty, 1990:159). Özellikle rekabetin yoğunlaşmasıyla birlikte, tüketicilerin dikkatlerini çekmek ve ürünlerini/hizmetlerini tüketicilerin zihinlerinde konumlandırmak isteyen işletmeler için ünlüleri kullanmak pazar paylarını artırmada büyük katkı sağlamaktadır (Croft vd., 1996). Bu sebeplerden dolayı reklamcıların ürünlerini temsil edebilen ve toplum tarafından kabul görmüş doğru ünlüyü bulmaları, daha çabuk rekabet avantajı kazanacakları sonucunu ortaya çıkarmıştır (Solomon vd., 2010).

Ünlü kullanımlarına ilişkin çalışmalar, genelde kaynak inanılırlığı ve kaynak çekiciliği modellerine göre yapılmaktadır. Kaynak inanılırlığı modeli, uzmanlık ve güvenirlilik faktörlerine dayandırılırken; kaynak çekiciliği modeli ise, tanınırlık, ünlü ile kurulan benzerlik, ünlüye duyulan beğeni ve fiziksel çekicilik faktörlerine dayandırılmıştır (Maddux ve Rogers, 1980). Kaynak inanılırlığı modeliyle, bir mesajın etkililiğinin kaynağın algılanan uzmanlığının ve güvenirliğinin düzeyine bağlı olduğu (Ohanian, 1991); inanılır bir kaynaktan gelen bilginin içselleştirme olarak adlandırılan bir süreç boyunca inançları, düşünceleri, tavırları ve 
davranışları etkileyebildiği; içselleştirme ile de, alıcıların kişisel tavırları ve değer yapıları açısından kaynağın etkisini onayladıkları zaman gerçekleştiği belirlenmiştir (Erdogan, 1999:297). Kaynak çekiciliği modeliyle ise, fiziksel çekiciliğin reklamlarda ünlü kullanılması neticesinde özdeşleştirme adı verilen süreç ile gerçekleştiği; özdeşleştirme sürecinin ise alıcının kaynak gibi olmayı arzulamasının bir sonucu olarak çekici bir kaynaktan gelen bilgiyi kabul ettiğini ve onayladığını varsaydığı belirlenmiştir (Cohen ve Golden 1972). Friedman ve Friedman (1979) özdeşleştirme süreci göz önüne alındığında ünlülerin, zevk ve beğeni içeren ürünlerin tanıtımında özellikle de yüksek psikolojik ve toplumsal risk içeren ürünlerde (Ör. mücevher gibi) daha başarılı oldukları sonucuna ulaşmışlardır. Ancak McCracken (1989) kaynak modellerin, ünlülerin etkililiğini ileri düzeyde anlamada çok sınırlı kaldığını belirtmiş ve anlam transferi modelinin ünlülerin reklamlarda kullanılmasını daha iyi bir şekilde açılayacağını savunmuştur. Bu modele göre ünlü kullanım sürecinde, ünlüler kendilerine ait sembolik anlamları bu sürece dahil ederler ve bir ünlüde var olan kültürel anlamlar kişinin ötesine geçerek ürünlere transfer olur. Aynı zamanda, ünlülerin karakteristik özellikleri itibariyle sınıf, statü, cinsiyet, yaş, karakter ve yaşam tarzına göre farklılıklar göstermesi, bu farklılıkların pazarlama sistemine uyarlanmasında önemli bir kriter olarak görülmüştür. McCracken (1989) ayrıca ünlülerin hedef tüketiciler nezdinde taşıdığı algıdan yola çıarak reklam mesajlarının çok etkili olduğunu, örnek olarak da Amerikalı sinema sanatçısı James Garner'ın Mazda reklamında başarılı olmasında onun sahip olduğu anlamsal ifade (Amerikalılığı, güveni, zekayı ve güzel espriden oluşan bir anlamlar demeti)ile Mazda'nın çizgisi arasındaki mükemmel uyumdan kaynaklandığını ifade etmiştir. Ünlü kullanılmasına ilişkin bir diğer model ise ürün eşleşimi modelidir. Bu model, ünlü ile ürün arasındaki uyumun etkili bir reklam için önemli olduğunu savunmaktadır (Kamins, 1990). Ünlü ve ürün arasındaki uyumun ölçüsü ürün ile ünlü imajı arasındaki algılanan uyumun derecesine göre değişiklik göstermektedir. Bir ürünün reklamını ürün ile yüksek bir şekilde uyum sağlayan ünlü ile yapmak ürün ile düşük şekilde uyum sağlamış olan ünlüyle reklam yapmaya göre daha etkili olmakta ve inandırıcılığını daha fazla etkilemektedir (Kamins ve Gupta 1994).

\section{SOSYAL MEDYA FENOMENLERI}

20. yüzyılda sıradan kişiler için sinema, müzik gibi endüstrilerde ünlü olmak oldukça zor olup tekel piyasa vasıtasıyla kimin ünlü olacağına, kimin yıldız yapılacağına karar verilmekteydi. $\mathrm{Bu}$ açıdan birçok insan için ünlü olmak bir hayaldi. Ancak 2000 yılının başlarında hayatımıza giren internetin her alanda yaygınlaşmasıyla birlikte bu durum değişime uğrayarak tarihte ilk kez sıradan kişilerin eğlence endüstrisini atlatarak (sosyal medyayı kullanmak suretiyle) bir ünlüye dönüşmelerini sağlandı (Cultureshop, 2015). Böylece günümüzde "ünlü" olma rüyası eskisinden daha kolay başarılmakta, sosyal medyanın gücü ile ünlü olmak için artık özel bir yeteneğe ihtiyaç duyulmamakta ve bu durum insanların sosyal medya hesaplarındaki takipçi sayısı ile ölçülmektedir (Ecmercer, 2015).

Marwick ve Boyd'a (2011) göre sosyal medya, ünlü olabilmek ve belirli bir kanalda bir grup kullanıcının dikkatini çekebilmek için insanlara büyük olanaklar sunmaktadır. Sosyal medya fenomenleri sosyal medyada fanlar ve farkındalık için yarışan kişiler oluşturmaktadır (Marwick ve Boyd, 2011). Günümüzde sosyal medya fenomeni olabilmek için ise, insanların sosyal medya kullanıcılarının dikkatini çekecek yeteneklere sahip olmaları gerekmektedir (Cultureshop,2015)

Clarewells (2014) sosyal medya fenomeni kavramını, sosyal medyayı kendi kitlesini oluşturmak için kullanan ve alışılmış yolla ünlü olmayan kişiler olarak ifade etmiştir. Bu kişiler, ünlü olabilmek için milyonlarca takipçiye sahip olmak zorunda değildirler. Sosyal medya fenomeni kavramı kendini markalaştırmayla ve stratejik kişisel sunumun popülaritesini artırmayla 
bağlantılı olan çevrimiçi ve çevrimdışı davranışların her ikisinin de geçerli bir tarzı olarak tanımlanmaktadır (Hearn, 2008; Lair vd., 2005). Senft (2012) sosyal medya fenomenlerinin alıcıların hem izleyici hem de bir topluluk olduğunu, izleyicilerin sadece dinlediğini; topluluğun ise etkileşim içinde olduğunu belirtmiştir. Bu da Senft'in 2008 yılında yapmış olduğu "yabancı aşinalık" terimini sunmasının sebebi olarak görülmüş ve bu terimin birbirini bilmeyen insanların birbirini tanımalarıyla ilgili olan "aşina yabancılar" terimine (Milgram ve Sabini, 1992), dayandığı belirlenmiştir. Bu bağlamda, tüketicilerin sosyal ağında yer alan sosyal medya fenomenlerinin tüketicilerin satın alma karar sürecinde doğrudan etkiye sahip olan kişiler olduğunu ortaya çıkarmıştır (Ruggless, 2013).

Sosyal medya aynı zamanda, sosyal medya fenomeni ile takipçisi arasında ortaya çıkan iki yönlü etkileşim sayesinde ürün ve hizmetlerin tüketiciler tarafından satın alınması için etkili bir yöntem ortaya koymaktadır (Choudhary, 2015). Ayrıca, sosyal ağı çevreleyen toplumsal ve kültürel, coğrafik, ekonomik ve finansal koşullar gibi kişiler arası etkileşimlerin yapısını etkileyen dişsal faktörler de tüketicinin satın alma davranışlarını etkileyebilmektedir (Brown ve Fiorella, 2013:142; Aktaran: Avcilar ve Açar, 2017).

Son zamanlarda Twitter, Facebook, Youtube, Vine ve Instagram gibi sosyal medya araçlarının hem ünlü hem de ünlü olmayan kişilerin geniş kitlelere ulaşabilmelerinde büyük avantajlar sağladığı görülmektedir (Marwick, 2015: 334). Böylece toplumda fanlar oluşturularak zihinlerde konumlandırılan mikro ünlüler, yeterince tüketicilerin zihninde pozitif bir alg1 oluşturmayan küçük işletmeler için ürünle tüketici arasında güçlü bir bağ kurmada çok önemli bir pazarlama stratejisi olarak karşımıza çıkmaktadır. Aynı zamanda mikro ünlüler farklı demografik özelliklere sahip tüketici gruplarına ulaşmak isteyen büyük işletmeler içinde uygun bir araç haline gelmiştir (Su A., 2017).

\section{INSTAGRAM REKLAMLARINDA SOSYAL MEDYA FENOMENİ KULLANIMI}

Instagram ilk olarak, fotoğraf çekmek ve çekilen bu fotoğrafları, Facebook, Twitter, Tumblr ve Flickr gibi sosyal medya kanallarındaki gibi farklı filtreler uygulandıktan sonra yayınlamak amacıyla sunulmuş bir akıllı telefon fotoğraf paylaşım uygulaması olarak insanların hayatına girmiştir (Benjamin, 2012). Günümüzde bu platform, farklı işletim sistemlerinde kullanılmakta ve neredeyse her tür cihaza kurulabilmektedir (Raice ve Spencer, 2012). Son zamanlarda pazarlamada en etkili sosyal medya uygulamalarından biri olan Instagram Kevin Systrom ve Mike Krieger tarafından oluşturulmuş ve 6 Ekim 2010 'da kullanılmaya başlanmıştır (Instagram, 2018). Günümüzde internet kullanıcılarının \%32'si (demografik özellikleri itibariyle \% 59'u 18-29 yaş aralığında) olan yaklaşık olarak 800 milyondan fazla kişi günlük aktif kullanıcı olarak Instagram'ı kullanmaktadır (Aslam S., 2018). Dünyada Instagram'ı aktif olarak kullanan 110 milyon üye ile ABD birinci sırada yerini alırken, ülkemiz ise 33 milyon üye ile dördüncü sırada yer almaktadır (Statista, 2018). Bu veriler uygulamanın kurulduğu günden bu yana inanılmaz derecede hızlı yükseldiğini (Raice ve Spencer,2012) ve bu büyüme hızının da her geçen yıl artarak devam ettiğini göstermektedir (Mint, 2015). Özellikle, Instagram akıllı telefon kullanıcıları arasında büyümeye devam etmekte (Ruggles, 2013), bu sosyal medya kanalının popülaritesi günlük 8346 kişiyle sürekli artış göstermektedir. Instagram fanlarının \%28'i sayfalarını günde defalarca kontrol etmekte ve yaklaşık olarak her gün 28 dakikalarını bu platformda harcamaktadırlar. Bu uygulama nispeten yeni sayılabilir olsa da genç tüketiciler arasında yaygın bir iletişim ağı olarak oldukça fazla kullanılmaktadır (Manikonda vd., 2014).

Instagram asıl olarak, bir insanın kendi ideal imajını oluşturduğu (Sunstrum, 2014) ve kullanıcıların kendilerine online bir imaj oluşturmak için çok fazla zaman harcadıkları bir platformdur. Bu sebeple, markalar savaşının yaşandığı günümüz dünyasında rekabet avantajı 
kazanmak isteyen her işletme yeni pazarlama stratejileri aramakta ve farklılık adına herkes tarafından tanınmış ve kabul görmüş ünlüler yerine belirli sayılarda takipçisi olan sosyal medya fenomenlerini ürün ve hizmetlerinin tanıtımında kullanmaktadırlar. Özellikle ürün ve hizmetlerinde Instagram üzerinden sosyal medya fenomeni kullanmak isteyen işletmelerin gerekçeleri, Instagram üzerindeki sosyal medya fenomenlerinin, ünlülerden daha az maliyetli ve daha kolay erişilebilir olması, hedef kitlenin dikkat ve ilgisini çekerek satın alma karar sürecinde farkındalık oluşturması ve satın alma karar sürecinde tüketici üzerinde doğrudan etkiye sahip olmasıdır. (Brown ve Fiorella, 2013, 142;Aktaran: Avcılar ve Açar, 2017).

\section{ARAŞTIRMANIN AMACI VE ÖNEMI}

Günümüz iş dünyasındaki rekabet daha önceki dönemlerle kıyaslanmayacak şekilde yoğun ve şiddetlidir. Böylesine zorlu bir rekabet ortamında işletmelerin pazara sundukları ürün ve hizmetler için farklılık oluşturacak stratejiler tasarlaması çok büyük önem arz etmektedir. Özelliklede işletmeler için, çok fazla reklam yığını arasından sıyrılıp tüketicilerin dikkatini çekebilmek giderek güç bir hal almıştır. Bu güçlüğü aşabilmek için reklamlara karşı tüketicilerin dikkatini çekebilmek ve bu dikkati sürdürebilmek için daha etkili araçların kullanılması gerektirmektedir. Bu araçlardan birisi de sosyal medya üzerinden ürün ve hizmetlere ilişkin reklamlarda sosyal medya fenomeni kullanılmasıdır. Sosyal medya fenomenleri küçük işletmelerin düşük bütçelerle ürün ve hizmetlerinin tanıtımında ve pozitif yönde marka ilişkisi kurmalarında fayda oluştururken; farklı demografik özelliklere yönelik tüketici gruplarına ulaşmak isteyen büyük işletmeler içinde uygun bir araç olarak fayda sağlamaktadır. Bu amaç doğrultusunda, tüketicilerin sosyal medya fenomenlerini neden takip ettikleri, satın alma kararı alırken sosyal medya fenomenlerinden etkilenip etkilenmedikleri, eğer etkileniyorlarsa nasıl ve ne şekilde etkilendikleri belirlenmeye çalışılmıştır.

\section{Araştırmanın Kısıtı ve Örneklem Seçimi}

$\mathrm{Bu}$ araştırma için ana kütle olarak Niğde Ömer Halisdemir Üniversitesi İktisadi ve İdari Bilimler Fakültesinde okuyan lisans öğrencileri alınmıştır. Söz konusu üniversitenin web sayfasında yer alan bilgiye göre 2017-2018 eğitim öğretim yılında 4530 lisans öğrencisi bulunmaktadır (ohu.edu.tr/sayilarla/). Ana kütlenin tamamına ulaşmak hem zaman yönünden hem de maliyet yönünden sıkıntılı olduğu için ana kütleyi en iyi temsil edecek örneklem yöntemi seçilmiştir. Bu doğrultuda, yapılan çalışmada söz konusu üniversitede eğitim/öğretim gören 376 öğrenciyle, 01.03.2018-06.04.2018 tarihleri arasında yüz yüze görüşme yöntemi ve ihtimalsiz örnekleme yöntemlerinden kolayca örnekleme yöntemi kullanılmıştır. Kolayca örnekleme yöntemi görüşme yapan uzman kişinin uygun gördüğü kişi ile anketi doldurması olarak ifade edilmiştir (Nakip, 2003: 784). Zaman ve maliyet sınırlaması nedeniyle araştırmanın sadece Niğde ilinde ve lisans öğrencilerine yapılmış olması araştırmanın bir kısıtıdır. Bu durum, Türkiye çapında genelleme yapmaya imkan vermemektedir. 


\section{Araştırma Modeli ve Hipotezler}

Kullanılan araştırma modeli aşağıda Şekil 1'de gösterilmiştir.

Şekil 1: Araştırmanın Modeli

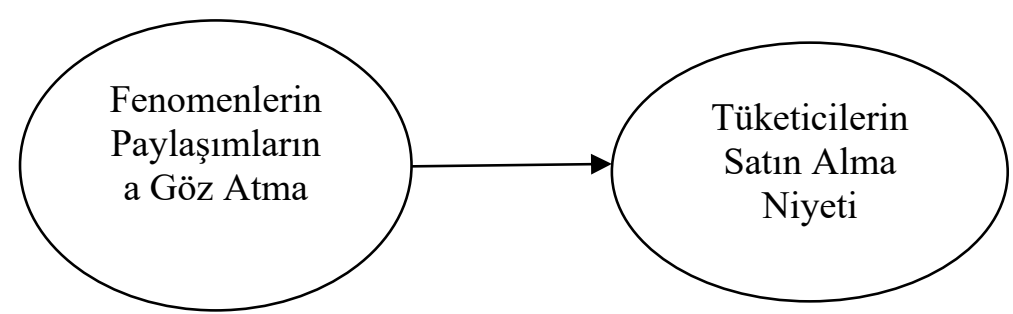

Araştırmanın amacı ve modeli doğrultusunda uygulamayla ilgili geliştirilen hipotez şu şekildedir.

\section{Hipotez}

H1: Tüketicilerin satın almayı düşündükleri ürünlere ilişkin sosyal medya fenomenlerinin paylaşımlarına göz atmasının tüketicilerin satın alma davranışı üzerinde olumlu etkisi vardır.

\section{Verilerin Toplanmasi}

Anket formunun hazırlanmasında 2016 yılında İsveç'te yapılan yüksek lisans tezinden faydalanılmış (Korotina, ve Jargalsaikhan, 2016) ve söz konusu çalışmada gerçekleştirilen odak grup görüşmesi sonuçlarından yararlanılarak anket soruları hazırlanmıştır. İlk olarak öğrencilere sosyal medya fenomeni ile ilgili şu bilgi verilmiş ve anketi cevaplamaya geçmeden önce öğrencilerin bu bilgiyi okumaları sağlanmıştır: "Birazdan size yöneltilen sorularda göreceğiniz "Sosyal medya fenomeni" kavramı bilinen şekilde (film yıldızı, sanatçı, popstar vb) ünlü olmadığı halde, katıldığı TV programları (survivor yarışması, evlilik programları vb.) ya da internet üzerinde paylaştığı videolar, blog içerikleri sayesinde sosyal medya üzerinde popüler hale gelmiş kişiler için kullanılmaktadır". Bu bilgi verildikten sonra öğrencilere Instagram üzerinde herhangi bir sosyal medya fenomeni takip edip etmedikleri sorulmuş ve bu soruya 'evet' cevabı veren katılımcılarla anket çalışmasına devam edilmiştir. Anketin diğer bölümlerinde katılımciların sosyal medya fenomenlerini neden takip ettikleri, Instagram üzerinde ürün inceleme içeriklerine bakıp bakmadıkları, ürünlerin satın alınması noktasında sosyal medya fenomenlerinden etkilenip etkilenmedikleri, sosyal medya fenomenleri ürünlere ilişkin paylaşımlar yaparken hangi durumlarda onlara olan güvenin yitirileceği ortaya çıkarılmaya çalışılmıştır. Anketin son bölümünde ise demografik sorular yer almıştır.

\section{Verilerin Analizi}

Yapılan çalışmada elde edilen verilerin analizlerinin yapılmasında, SPSS programından faydalanılmıştır. Bu program yardımıyla ankette yer alan soruların frekans dağılımı, aritmetik ortalaması ve yüzdeleri hesaplanmıştır. Ayrıca, sosyal medya ile ilgili yargılardaki değişken sayısını azaltmak için faktör analizi kullanılmış, hipotez ise regresyon analizi ile test edilmiştir. 


\section{Katılımcilarn Sosyal medya Fenomenleri Takip Etme Durumu}

Katılımclara Instagram üzerinden herhangi bir sosyal medya fenomenini takip edip etmedikleri sorulmuş bu soruya 'hayır' cevabı veren katılımcılar için anket sonlandırılmıştır.

Tablo 1: Katılımciların Sosyal Medya Fenomenlerini Takip Etme Durumu

\begin{tabular}{|l|c|c|}
\hline \multicolumn{2}{|c|}{ Instagram Üzerinde Herhangi Bir Sosyal Medya Fenomenini Takip Ediyor Musunuz? } \\
\hline Hayır & 197 & $\% 52,4$ \\
\hline Evet & 179 & $\% 47,6$ \\
\hline Toplam & 376 & $\% 100$ \\
\hline
\end{tabular}

Tablo 1 incelendiğinde 197 katılımcının (\%52,4) hayır cevabı verdiği 179 katılımcının $(\% 47,6)$ ise evet cevabı verdiği görülmektedir. Bundan sonraki araştırmaya "Evet" cevabı veren 179 katılımc ile devam edilmiştir.

\section{Örneklemin Demografik Yapisı}

$\mathrm{Bu}$ bölümde mevcut çalışmanın uygulanmış olduğu örneklemin cinsiyet ve yaşa ilişkin demografik özellikleri istatistiksel olarak gösterilmektedir.

Tablo 2: Araştırmaya Katılan Öğrencilerin Demografik Özelliklerinin Dağılımı

\begin{tabular}{|l|l|l|l|l|l|}
\hline Cinsiyet & \multicolumn{3}{l|}{ Yaş } \\
\hline Kadın & 100 & $\% 55,9$ & $18-20$ & 45 & $\% 25,1$ \\
\hline Erkek & 79 & $\% 44,1$ & $21-23$ & 59 & $\% 33,0$ \\
\hline & & $24-26$ & 58 & $\% 32,4$ \\
\cline { 4 - 7 } & 27 ve üstü & 17 & $\% 9,5$ \\
\cline { 3 - 7 }
\end{tabular}

Tablo 2'ye göz atıldığında örneklemin cinsiyet dağılımında kadın katılımcıların oranının erkek katılımcılara nazaran fazla olduğu görülmektedir. Örneklemin tamamının öğrenci olması nedeniyle, yaş dağılımında 18-26 yaş aralığının çoğunlukta olduğu görülmektedir. 18-26 yaş aralığındaki katılımcı sayısı örneklemin \% 90,5'ini oluşturmaktadır.

\section{Araştırmanın Bulguları ve Değerlendirme}

Araştırmada 5'li Likert ölçeği kullanılmış olup (1: kesinlikle katılmıyorum, 2: katılmıyorum, 3: fikrim yok, 4: katıllyorum, 5: kesinlikle katılıyorum) şeklinde ifade edilmiştir. Anket katılımcılarına ilk olarak sosyal medya fenomenlerini neden takip ettikleri sorulmuş ve katılımcıların sosyal medya fenomenlerini takip etme nedenleri ortaya çıkarılmaya çalışılmıştır. Yargılara ait ortalama değerler Tablo 3 de verilmiştir: 
Tablo 3: Katılımcıların Sosyal Medya Fenomenlerini Takip Etme Nedenlerine İlişkin Ortalama Değerler

\begin{tabular}{|l|l|l|}
\hline Sıra & \multicolumn{1}{|c|}{ YARGILAR } & ORT. \\
\hline 1 & $\begin{array}{l}\text { Sosyal medya fenomenlerini takip ederim; çünkü sıradan insanlarla-ünlüler } \\
\text { arasında bir yerde olduklarını düşünüyorum. }\end{array}$ & 3,62 \\
\hline 2 & $\begin{array}{l}\text { Sosyal medya fenomenlerini takip ederim; çünkü erişilebilir yaşam tarzlarının } \\
\text { olduğunu düşünüyorum. }\end{array}$ & 3,75 \\
\hline
\end{tabular}

Tablo 3'deki değerlere göre katılımcıların yukarıdaki her iki yargıya da katıldıkları görülmektedir. Buna göre sosyal medya fenomenleri sıradan insanlarla-ünlüler arasında bir yerde olduklarından ve erişilebilir bir yaşam tarzına sahip olduklarından takip edilmektedir. Buradan katılımciların sosyal medya fenomenlerini kendilerine daha yakın hissettiği ve onlarla benzerlik kurduğu sonucuna ulaşılabilir. Bu açıdan değerlendirildiğinde tüketiciler sosyal medya fenomenlerinin vereceği tavsiyeleri daha gerçekçi bulabilirler. Çünkü sosyal medya fenomenlerinin kendi yaşam tarzlarına yakın bir şekilde yaşadıklarını düşünmektedirler. Ardından Instagram üzerindeki sosyal medya fenomenlerinin katılımcıların satın alma davranışlarına etkisi ortaya çıkarılmaya çalışılmıştır. Yargılara ait ortalama değerler Tablo 4 de verilmiştir:

Tablo 4: Instagram Üzerindeki Sosyal Medya Fenomenlerinin Katılımcıların Satın Alma Davranışlarına Etkisine İlişkin Ortalama Değerler

\begin{tabular}{|c|c|c|}
\hline Sira & YARGILAR & ORT. \\
\hline 1 & Instagramdaki ürün inceleme içeriklerine bakarım. & 3,70 \\
\hline 2 & $\begin{array}{l}\text { Bir mağazaya gittiğimde bir ürünü almak isteği oluştuğunda daha sonra o ürünü } \\
\text { Instagramda gördüğümü hatırlarım. }\end{array}$ & 3,68 \\
\hline 3 & $\begin{array}{l}\text { Satın almayı düşündüğüm ürünlere ilişkin Sosyal medya fenomenlerinin } \\
\text { paylaşımlarına göz atarım. }\end{array}$ & 3,73 \\
\hline 4 & $\begin{array}{l}\text { Sosyal medya fenomeni tarafından tanıtımı yapılan ürüne ilişkin arkadaşlarımın } \\
\text { fikirlerini de sorarım. }\end{array}$ & 3,91 \\
\hline 5 & Instagram'da Fenomenin tanıttığı ürün beni etkiler. & 3,70 \\
\hline 6 & $\begin{array}{l}\text { Fenomenin bir ürüne ilişkin verdiği olumlu tavsiye satın alma kararımı olumlu } \\
\text { etkiler. }\end{array}$ & 3,76 \\
\hline 7 & $\begin{array}{l}\text { Instagramda sosyal medya fenomeni tarafından tanitılan bir ürünü satın almak } \\
\text { isterim. }\end{array}$ & 3,87 \\
\hline 8 & $\begin{array}{l}\text { Sosyal medya fenomenlerinin paylaşmış olduğu indirim kuponları satın alma } \\
\text { kararımı olumlu etkiler. }\end{array}$ & 3.96 \\
\hline 9 & $\begin{array}{l}\text { Fenomenin bir ürünle birlikte resim paylaşması o ürüne karşı satın alma istediği } \\
\text { uyandırır. }\end{array}$ & 3.56 \\
\hline
\end{tabular}


Tablo 4'deki değerlere göre katılımcların yukarıdaki yargıların hepsine katıldıkları görülmektedir. Buna göre katılımcılar Instagramdaki ürün inceleme içeriklerine bakmakta ve herhangi bir mağazaya gittiğinde bir ürünü satın alma istediği oluştuğunda o ürünü Instagramda gördüğünü hatırlamaktadır. Bu açıdan Instagramın giderek artan popülaritesi de göz önüne alındığında işletmelerin Instagram üzerinde yer alması çok önemli hale gelmektedir. Ürünlere ilişkin tanıtımlarda Instagram genç tüketicilere ulaşmak için önemli bir araç haline gelmektedir.

Sosyal medya fenomenlerine ilişkin yargılar incelendiğinde katılımcıların fenomenlerin paylaşımlarına göz attığı, tanıttıkları ürünlerden etkilendiği, fenomenin bir ürüne ilişkin verdiği olumlu tavsiyenin satın alma kararlarını olumlu etkilediği ve belki de en çarpıcısı fenomen tarafından tanıtılan bir ürünü satın almak istemeleridir. Sonuçların böyle çıması, katılımcıların sosyal medya fenomenlerini kendilerine yakın bulmalarıyla ve onlarla benzerlik kurmalarıyla açıklanabilir. Katılımcılar bir ürünü satın almadan önce kendileri gibi bir yaşam tarzına sahip olduklarını düşündükleri sosyal medya fenomenlerinin paylaşımlarına göz atmakta ve onların tavsiyelerini dikkate almaktadır. Sosyal medya fenomenlerinin ürünlere ilişkin yaptığı tanıtımdan etkilenmekte ve o ürünü satın almak istemektedirler. Bu açıdan değerlendirildiğinde işletmelerin genç tüketicilere ulaşmak için sosyal medya fenomenlerinden faydalanmaları çok faydalı bir taktik olacaktır. Belirli hedef kitlesi olan, verdiği tavsiye takipçileri tarafından dikkate alınan bir sosyal medya fenomeniyle ürün ve hizmetlere ilişkin tanıtımlar yapmak, günümüzdeki reklam yığını içerisinden sıyrılıp tüketicilerin dikkati çekmede ve onlara ulaşmada önemli bir araç haline gelmektedir.

Katılımcılar ayrıca sosyal medya fenomenlerinin paylaşmış olduğu indirim kuponunun satın alma isteklerini olumlu etkilediğini ve sosyal medya fenomeninin bir ürünle birlikte resim paylaşmasının o ürüne ilişkin satın alma isteği uyandırdığını belirtmişlerdir.

Ancak indirim kuponunun paylaşılmasından daha çok etkilenmektedirler. Bu açıdan değerlendirildiğinde sosyal medya fenomeni tarafından tanıtımı yapılan ürünlerle birlikte paylaşılacak indirim kuponları genç tüketicilerin satın alma ihtimallerini daha da artıracaktır.

Katılımcıların sosyal medya fenomenlerinin paylaşımlarına duydukları güvene ait ortalama değerler ise Tablo 5'de gösterilmiştir:

Tablo 5: Tüketicilerin Instagram Üzerindeki Sosyal Medya Fenomenlerinin Paylaşımlarına Karşı Güvene İlişkin Ortalama Değerler

\begin{tabular}{|l|l|l|}
\hline 1 & Fenomenin paylaştığı içeriğin aldatıcı olduğunu düşünürsem takibi bırakırım. & 4,38 \\
\hline 2 & $\begin{array}{l}\text { Fenomenin paylaştığı içeriğin para kazanma amaçlı olduğunu düşünürsem takibi } \\
\text { bırakırım. }\end{array}$ & 4,14 \\
\hline 3 & $\begin{array}{l}\text { Fenomenin paylaştığı içeriğin aldatıcı olduğunu düşünürsem sosyal medya } \\
\text { fenomenine karşı güvenimi yitiririm. }\end{array}$ & 4,39 \\
\hline 4 & $\begin{array}{l}\text { Fenomenin paylaşımının doğrudan reklam olduğunu düşünürsem o paylaşımı } \\
\text { dikkate almam. }\end{array}$ & 4,16 \\
\hline
\end{tabular}

Tablo 5'deki değerlere göre tüketiciler sosyal medya fenomenin paylaştığı içeriğin aldatıcı olduğunu, para kazanma amaçlı olduğunu düşündüklerinde takibi bırakmaktadırlar. Ayrıca sosyal medya fenomenin paylaştığı içeriğin aldatıcı olduğunu düşündüklerinde sosyal medya 
fenomenine karşı güvenlerini yitirmekte ve paylaşımın doğrudan reklam olduğunu düşündüklerinde paylaşımı dikkate almamaktadırlar. Bu sonuçlar sosyal medya fenomenleri kullanılarak yapılan reklamlarda çok dikkatli ve titiz davranılması gerektiğini göstermektedir. Sosyal medya fenomeninin yaptığı paylaşımların tüketiciler tarafından doğrudan reklam ve para kazanma amaçlı olduğu algısı oluşturulmadan ilgili ürünlerin tanıtımları yapılmalıdır. Sosyal medya fenomeni örneğin bir ayakkabı tanıtımı yapıyorsa bu ayakkabıyı gerçekten kendisi kullandığı için, beğendiği için takipçileriyle paylaştığı algısı oluşturulması tüketicilerin satın alma davranışlarının etkilenmesi açısından çok önemli olacaktır. Bu açıdan değerlendirildiğinde sosyal medya fenomeninin sürekli olarak ürün tanıtımı yapması, aynı kategoride farklı farklı markaların ürünlerini tanıtması inandırıcılığını azaltacak ve tüketicilerin bu tanıtımların sadece para kazanma amaçlı olduğu sonucunu çıkarmalarına yol açacaktır.

Katılımclara son olarak Instagram üzerindeki sosyal medya fenomenleri tarafından tanıtılan hangi ürünü daha fazla alırsınız/almak istersiniz? sorusu yönetilmiştir. Yanıtlara ait ortalama değerler Tablo 6 da gösterilmiştir:

Tablo 6: Instagram Üzerindeki Sosyal Medya Fenomenleri Tarafından Tanıtılan Ürünlerin Katılımcılar Tarafından Satın Alınma İsteğine İlişkin Ortalama Değerler

\begin{tabular}{|l|l|c|}
\hline Sira & \multicolumn{1}{|c|}{ Ürünler } & ORT.(\%) \\
\hline 1 & Giyim Ürünleri & 39,7 \\
\hline 2 & Kozmetik Ürünler & 22,9 \\
\hline 3 & Kitap-Dergi & 19,0 \\
\hline 4 & Elektronik Ürünler & 16,8 \\
\hline 5 & Yiyecek-İçecek & 1,7 \\
\hline \multicolumn{2}{|l|}{ Toplam } & 100 \\
\hline
\end{tabular}

Tablo 6'daki değerlere göre katılımcılar en fazla sosyal medya fenomenleri tarafından tanıtılan giyim ürünlerini satın almaya istekli olurken; yiyecek-içecek ile ilgili ürünlere ise ilgi göstermemektedirler. $\mathrm{Bu}$ açıdan değerlendirildiğinde işletmeler tarafından sosyal medya fenomenlerinin giyim ürünleri tanıtımında kullanılması daha etkili bir strateji olacaktır. Tüketicilerin fenomenlerin tanıttı̆̆ giyim ürünlerini satın almaya istekli olmaları şu şekilde açılanabilir: Tüketiciler, fenomenleri sıradan insanlar olarak görmekten ziyade onları ünlü birisi gibi değerlendirmektedir. Ünlü olarak değerlendirilen fenomenler, tüketicilere çekici gelmektedir. Çekici olarak algılanan fenomenler ise giyim ürünleri gibi psikolojik-sosyal riski yüksek ürünlerin satın alma kararında tüketicileri etkilemektedir. Yukardaki tablo da kozmetik ürünlerin de hemen ikinci sırada gelmesi de aynı şekilde açıklanabilir. Kitap-dergi ürünlerinin üçüncü sırada çıkması da önemli bir sonuç olarak değerlendirilmelidir. Instagrama incelediğimizde genelde sosyal medya fenomenlerinin giyim ürünleri ve kozmetik ürünlerin tanıtımını yaptıkları görülecektir. Kitap-dergi tanıtımı yapan sosyal medya fenomeni neredeyse yok gibidir. Bu çalışmadan elde edilen bu bulgu sonucunda işletmelerin kitap-dergi gibi ürünlerin tanıtımında da sosyal medya fenomeni kullanmalarının etkili bir strateji olabileceği söylenebilir. 


\section{Araştırma Yöntemi}

\section{Faktör ve Güvenilirlik Analizi}

Yapılan araştırma sonucu elde edilen veri setine SPSS programından faydalanılarak keşifsel faktör analizi uygulanmıştır. Yapılan keşifsel faktör analizi sonucunda bütün değişkenlere KMO (Kaiser-Meyer-Olkin) ve Barlett testleri yapılmış olup analize tabi tutulan değişkenlerin sonucuna bakılarak faktör analizine uygun olup olmadıkları test edilmiştir. Bütün değişkenlerin, KMO testi 0,5'den büyük olması gerekmektedir (Albayrak vd., 2005: 322). Gözlenen korelasyon katsayılarının büyüklüğü ile kısmı korelasyon katsayılarının büyüklüğü karşılaştırılmış, küçük çıkması durumunda çift olarak değişkenler arasındaki korelasyon ilişkisinin diğer değişkenlerce açılanmayacağı tespit edilmiştir. Bu durumda faktör analizine devam etmek doğru olmaz. KMO bir oran olup \%60'ın üstünde olması arzulanır (Nakip, 2003:408). Yapılan çalışmada KMO testi sonucu \% 84,4 olarak belirlenmiştir. Ayrıca, özdeğeri (Eigenvalue) 1'den büyük olan faktörler anlamlı kabul edilir (Albayrak vd., 2005: 322) ve Barlett testinin ise 0.05 'den küçük olması gerekmektedir.

Genellikle Cronbach's Alfa $(\alpha)$ Katsayısının alt limiti olarak 0,70 kabul edilmektedir. Ancak, keşfedici araştırmalarda Cronbach's Alfa $(\alpha)$ Katsayısının 0,60'ın üstünde olması ölçeğin güvenilir olduğunu gösterir (Hair vd., 1998: 118; Yaraş, 2004: 85).

Tablo 7: KMO ve Barlett Test Sonuçları

\begin{tabular}{|l|l|}
\hline Kaiser Meyer Olkin (KMO) & 0,949 \\
\hline Barlett testi (Yaklaşık Ki kare Değeri ) & 6610,995 \\
\hline Serbestlik Derecesi (df.) & 91 \\
\hline Anlamlılık Düzeyi (sign.) & .000 \\
\hline
\end{tabular}

Tablo 7'de KMO testi sonucu \% 94,9 olarak belirlenmiştir. KMO testinin \% 60'dan büyük ve Bartlett testi sonucunun $(0,00<0,05)$ ve değişkenler arasında oluşan korelasyon katsayılarının \% 30 ve üzerinde olması durumu, veri setinin faktör analizine uygun olduğu sonucunu vermektedir. Bu çalışmada, KMO (\% 94,9) ve Bartlett testi sonuçlarına göre bu bilgiler ışığında veri setinin faktör analizine uygun olduğu görülmektedir. Ayrıca ölçeklere ait Cronbach's Alpha katsayılarına bakıldığında, katsayıların 0,920 ile 0,842 arasında değiştiği görülmekte olduğundan ölçekler güvenilirdir.

Çalışmada birinci faktör, "Fenomeni Takip Gerekçesi" olarak adlandırılmıştır. Bu faktörünün özdeğeri 4,245'tir ve toplam varyansın \%30,058'ini açıklamaktadır. Bu faktörün ortalama değeri 3,70 olarak çıkmıştır. Cronbach's Alpha değeri ise (\% 92) olarak çıkmış ve oldukça güvenilirdir.

Faktör analizi sonucunda elde edilen ikinci faktör, "Fenomenin Gücü" olarak adlandırılmıştır. İkinci faktörün özdeğeri, 4,380'dir ve toplam varyansın \%21,397'sini açıklamaktadır. “Bu faktörün ortalama değeri 3,77 olarak çıkmıştır. Cronbach's Alpha değeri ise $(\% 84,8)$ olarak çıkmış ve oldukça güvenilirdir. 
Tablo 8: Sosyal Medya Fenomenlerinin Tüketicilerin Satın Alma Davranışları Etkisine Yönelik Faktör Analizi Sonuçları

\begin{tabular}{|c|c|c|c|c|c|}
\hline Değişkenler & $\begin{array}{l}\text { Faktör } \\
\text { Yükleri }\end{array}$ & Özdeğer & $\begin{array}{l}\text { Açıklanan } \\
\text { Varyans } \\
\text { Yüzdesi }\end{array}$ & Ortalama & $\begin{array}{l}\text { Cronbach's } \\
\text { Alpha }\end{array}$ \\
\hline Faktör 1: Fenomeni Takip Gerekçesi & & \multirow{3}{*}{4,245} & \multirow{3}{*}{30,058} & \multirow{3}{*}{3,70} & \multirow{3}{*}{0,920} \\
\hline $\begin{array}{l}\text { Sosyal medya fenomenlerini takip } \\
\text { ederim; çünkü sıradan insanlarla- } \\
\text { ünlüler arasında bir yerde olduklarını } \\
\text { düşünüyorum. }\end{array}$ & ,771 & & & & \\
\hline $\begin{array}{l}\text { Sosyal medya fenomenlerini takip } \\
\text { ederim; çünkü erişilebilir yaşam } \\
\text { tarzlarının olduğunu düşünüyorum. }\end{array}$ & ,742 & & & & \\
\hline Faktör 2: Fenomenin Gücü & & \multirow{6}{*}{4,380} & \multirow{6}{*}{21,397} & \multirow{6}{*}{3,77} & \multirow{6}{*}{0,848} \\
\hline $\begin{array}{l}\text { Satın almayı düşündüğüm ürünlere } \\
\text { ilişkin Fenomenin paylaşımlarına göz } \\
\text { atarım. }\end{array}$ & ,0703 & & & & \\
\hline $\begin{array}{l}\text { Fenomen tarafından tanıtımı yapılan } \\
\text { ürüne ilişkin arkadaşlarımın fikirlerini de } \\
\text { sorarım. }\end{array}$ & ,707 & & & & \\
\hline $\begin{array}{l}\text { Instagram'da Fenomenin tanıttığı ürün } \\
\text { beni etkiler. }\end{array}$ & 698 & & & & \\
\hline $\begin{array}{l}\text { Fenomenin bir ürüne ilişkin verdiği } \\
\text { olumlu tavsiye satın alma kararımı } \\
\text { olumlu etkiler. }\end{array}$ & ,712 & & & & \\
\hline $\begin{array}{l}\text { Instagramda Fenomen tarafından } \\
\text { tanıtılan bir ürünü satın almak isterim. }\end{array}$ & ,715 & & & & \\
\hline $\begin{array}{l}\text { Faktör 3: Fenomenin Paylaşımlarına } \\
\text { Karşı Duyarlılık }\end{array}$ & & \multirow{5}{*}{5,432} & \multirow{5}{*}{20,123} & \multirow{5}{*}{4,20} & \multirow{5}{*}{0,842} \\
\hline $\begin{array}{l}\text { Fenomenin paylaştığı içeriğin aldatıcı } \\
\text { olduğunu düşünürsem takibi bırakırım. }\end{array}$ & 697 & & & & \\
\hline $\begin{array}{l}\text { Fenomenin paylaştı̆̆ı içeriğin para } \\
\text { kazanma amaçlı olduğunu düşünürsem } \\
\text { takibi bırakırım. }\end{array}$ & ,712 & & & & \\
\hline $\begin{array}{l}\text { Fenomenin paylaştığı içeriğin aldatıcı } \\
\text { olduğunu düşünürsem sosyal medya } \\
\text { fenomeniye karşı güvenimi yitiririm. }\end{array}$ & ,718 & & & & \\
\hline $\begin{array}{l}\text { Fenomenin paylaşımının doğrudan } \\
\text { reklam olduğunu düşünürsem o } \\
\text { paylaşımı dikkate almam. }\end{array}$ & ,701 & & & & \\
\hline
\end{tabular}


Faktör analizi sonucunda elde edilen üçüncü faktör, "Fenomenin Paylaşımına Karşı Duyarlılık" olarak adlandırılmıştır. Üçüncü faktörün özdeğeri, 5,432'dir ve toplam varyansın \%18,462'sini açıklamaktadır" Sosyal Medyanın Etkileşim Gücü” ortalama değeri 4,20 olarak çıkmıştır. Cronbach's Alpha değeri ise $(\% 84,2)$ olarak çıkmış ve oldukça güvenilirdir.

\section{Hipotez Testi}

Bu bölümde araştırma modeli doğrultusunda geliştirilmiş olan hipotez Regresyon yöntemiyle test edilmiş ve sonuçları yorumlanmıştır.

H1: Tüketicilerin satın almayı düşündükleri ürünlere ilişkin sosyal medya fenomenlerinin paylaşımlarına göz atmasının tüketicilerin satın alma davranışı üzerinde olumlu etkisi vardır.

Hipotez regresyon analizi ile test analiz edilmiştir. Analize ilişkin sonuçlar Tablo 9'da gösterilmektedir:

Tablo 9: Hipotez Testine İlişkin Veriler

\section{Model Summary}

\begin{tabular}{|l|r|r|r|c|}
\hline Model & $\mathrm{R}$ & $\mathrm{R}$ Square & \multicolumn{1}{|c|}{$\begin{array}{c}\text { Adjusted } \mathrm{R} \\
\text { Square }\end{array}$} & $\begin{array}{c}\text { Std. Error of the } \\
\text { Estimate }\end{array}$ \\
\hline 1 &, $980^{\mathrm{a}}$ &, 960 &, 959 &, 15966 \\
\hline
\end{tabular}

a. Predictors: (Constant), Satınalma

\begin{tabular}{|c|c|c|c|c|c|c|}
\hline \multicolumn{7}{|c|}{ Coefficients $^{a}$} \\
\hline \multirow{2}{*}{\multicolumn{2}{|c|}{ Model }} & \multicolumn{2}{|c|}{ Unstandardized Coefficients } & \multirow{2}{*}{$\begin{array}{c}\text { Standardized } \\
\text { Coefficients } \\
\text { Beta }\end{array}$} & \multirow[t]{2}{*}{$\mathrm{t}$} & \multirow[t]{2}{*}{ Sig. } \\
\hline & & $B$ & Std. Error & & & \\
\hline & (Constant) & 080 & ,085 & & ,941 & ,349 \\
\hline 1 & $\begin{array}{l}\text { Paylaşıma } \\
\text { Göz Atma }\end{array}$ & ,976 & ,019 & ,980 & 51,920 &, 000 \\
\hline
\end{tabular}

a. Dependent Variable: Satınalma

Buna göre $\beta=, 980 ; p=0,000$ olduğu için fenomenlerin paylaşımlarına göz atmanın tüketicilerin satın alma davranışını etkilemektedir. Bu sonuç fenomenlerin tüketiciler tarafından hem sıradan arkadaşlardan birisi gibi algılanarak inanılır bulunması hem de ünlüler gibi çekici algılanarak etkileyici bulunması ile açıklanabilir. Fenomenlerin ünlüler gibi değerlendirilmesi onların çekici olarak algılanmalarını sağlamaktadır. Böylece özellikle giyim ve kozmetik ürünleri gibi psikolojik-sosyal riskleri yüksek ve çekicilikle ilişkili ürünlerin tanıtımında daha fazla satın alma isteği uyandırmaktadırlar. 


\section{SONUÇ}

Rekabet savaşlarının her geçen gün daha da şiddetlendiğini göz önüne alındığında işletmelerin pazarlama iletişim aktivitelerinde daha farklı ve etkili yöntemler kullanmaları gerektiği açıtır. Günümüz dünyasında özellikle çok fazla reklam yığını arasından sıyrılarak, tüketicilerin dikkatini çekebilmek giderek güç bir hale gelmiştir. Bu güçlügü aşabilmek için reklamlara karşı tüketicilerin dikkatini çekebilmek ve bu dikkati sürdürebilmek için daha etkili araçların kullanılması gerektirmektedir. Ürünlerin tanıtımında sosyal medya fenomenlerinin kullanılması bu yöntemlerden birisi olarak öne çıkmaktadır. Sosyal medya fenomenleri küçük işletmelerin düşük bütçelerle ürün ve hizmetlerinin tanıtımında ve pozitif yönde marka ilişkisi kurmalarında fayda oluştururken; farklı demografik özelliklere yönelik tüketici gruplarına ulaşmak isteyen büyük işletmeler içinde uygun bir araç olarak fayda sağlamaktadır.

Katılımclara sosyal medya fenomenlerini takip etme nedenleri sorulmuş ve takip etme nedeni olarak sosyal medya fenomenlerinin erişilebilir bir yaşam tarzına sahip olmaları tüketicilerin en fazla katıldığ1 yargı olmuştur. "Sosyal medya fenomenlerini takip ederim; çünkü sıradan insanlarla-ünlüler arasında bir yerde olduklarını düşünüyorum" yargısını da katılmışlardır. Literatürde, reklamlardaki mesajların ikna edici olmasına etki eden kayna faktörler (kaynak inanılırlığı ve çekiciliği) üzerinde sıklıkla durulmaktadır. Kaynak inanılırlığı güvenilirlik ve uzmanlık faktörlerinden oluşurken; kaynak çekiciliği tanınırlık, benzerlik ve beğenilirlikten oluşmaktadır. Tüketiciler sosyal medya fenomenlerini kendilerine daha yakın hissetmektedirler. Ünlülerin erişilmez gibi duran yaşam tarzları göz önüne alındığında sosyal medya fenomenleri daha erişilebilir bir yaşam tarzını tüketicilere sunmaktadırlar. Ayrıca tüketicilerin fenomenleri, ünlülerle sıradan kişiler arasında bir yerde görmeleri de onları daha inandırıcı bulmalarını sağlamaktadır. Fenomenler hem sıradan bir kişi gibi tüketicilere yakın olurken, hem de ünlüler gibi çekici özelliklere sahip olmaları sebebiyle, tüketicilerin ilgisini çekmektedir. Böylece fenomenler etkileyici birer kaynak olmaktadırlar.

Katılımciların sosyal medya fenomenleri tarafından tanıtımı yapılacak olan ürünlerden en fazla giyim ürünlerini tercih edecekleri tespit edilmiştir. Instagrama göz atıldığında genelde sosyal medya fenomenlerinin giyim ürünlerinin tanıtımını yaptığı görülmektedir. Araştırmada ortaya çıkan bulgular ışığında bunun doğru bir strateji olduğu söylenebilir. İkinci olarak en fazla tercih edilecek ürünün kozmetik ürünleri olduğu tespit edilmiştir. Fenomenler giyim ve kozmetik ürünlerinin tanıtımında etkili tanıtıcılar olacaklardır. Özellikle çekici olarak algılanan fenomenlerin bu tür ürünlerin reklaminda kullanılması tüketicilerin ikna edilmesinde daha önemli olacaktır. Diğer taraftan kitap-dergi ürünlerinin tanıtımında da fenomenlerin satın alma isteğine etkisi olduğu ortaya çıarılmıştır. Ancak Instagram üzerindeki sosyal medya fenomenleri çok nadir olarak kitap-dergi ürünlerin tanıtımını yapmaktadır. Bu açıdan değerlendirildiğinde özellikle genç tüketicileri hedef alan işletmelerin kitap-dergi gibi ürünlerinin tanımında sosyal medya fenomenleri kullanmaları onlar için bir avantaj oluşturacaktır.

Araştırma bulguları dikkate alındığında katılımcılar sosyal medya fenomenlerinin paylaşımlarına göz atmakta, tanıttıkları ürünlerden etkilenmekte, sosyal medya fenomeninin bir ürüne ilişkin verdiği olumlu tavsiye satın alma kararlarını olumlu etkilemekte ve belki de en çarpıcısı sosyal medya fenomeni tarafından tanıtılan bir ürünü satın almak istemektedirler. Bu durum fenomenlerin tüketiciler tarafında hem sıradan arkadaşlardan birisi gibi algılanarak inanılır bulunması hem de ünlüler gibi çekici algılanarak etkileyici bulunması ile açıklanabilir. Katılımclar ayrıca sosyal medya fenomeninin paylaşmış olduğu indirim kuponunun satın alma isteklerini olumlu etkilediğini ve sosyal medya fenomeninin bir ürünle birlikte resim 
paylaşmasının o ürüne ilişkin satın alma isteği uyandırdığını belirtmişlerdir. Ancak indirim kuponunun paylaşılmasından daha çok etkilenmektedirler.

Ayrıca, katılımcıların sosyal medya fenomenlerinin paylaşımlarına ilişkin duydukları güvene ilişkin davranışları da belirlenmeye çalışılmıştır. Buna göre göre tüketiciler sosyal medya fenomeninin paylaştığı içeriğin aldatıcı olduğunu, para kazanma amaçlı olduğunu düşündüklerinde takibi bırakmaktadırlar. Ayrıca sosyal medya fenomeninin paylaştığı içeriğin aldatıcı olduğunu düşündüklerinde sosyal medya fenomenine karşı güvenlerini yitirmekte ve paylaşımın doğrudan reklam olduğunu düşündüklerinde paylaşımı dikkate almamaktadırlar.

Bu çalışmadan elde edilen sonuçların yorumlanmasına ve kullanılmasına yönelik bilgilerin hem bu alanda akademik çalışma yapmayı düşünen kişilere, hem de işletme yöneticilerine kararlarında büyük katkı sağlayacağı düşünülmektedir.

\section{KAYNAKÇA}

Albayrak, A. Sait; Abdullah Eroğlu; Şeref Kalaycl; Engin Küçüksille ve Belma Ak (2005). SPSS Uygulamalı Çok Değişkenli İstatistik Teknikleri, Asi Yayın Dağıtım LTD.ŞTİ, 1. Baskı, Ankara.

Avcılar, M. ve Açar, F. (2017). Sosyal Medya Reklamlarında Ünlü Desteği Kullanımı: Sosyal medya fenomenilerin Yükselişi, 15. Uluslararası Türk Dünyası sosyal Bilimler Kongresi (11-12 Eylül 2017).

Aslam S. (2018). Instagram by the Numbers: Stats, Demographics \& Fun Facts, https://www.omnicoreagency.com/Instagram-statistics/, (Erişim Tarihi:17.02.2018).

Benjamin, K. (2012). Instagram, Haymarket Business Publications, 25(23), 1.

Choudhary V. (2015). Instagram users in India to start receiving ads soon,https://www.livemint.com/Consumer/hVrCSRZQqbUi8bBpITVSfN/Instagram-users-tostart-receiving-advertisements-soon.html, (Erişim Tarihi:17.02.2018).

Clarewells, D. (2014). Micro-Celebrities and Social Media, https://clarewells.wordpress.com/2014/04/14/micro-celebrities-and-social-media. (17.02.2018).

Cohen, B. and Golden, E. (1972). Informational Social Influence and Product Evaluation, Journal of Applied Psychology, 56, February,54-59.

Croft, R., Dean, D., and Kitchen, P. (1996). Word-of-Mouth Communication: Breath of Life or Kiss of Death? In: The Proceedings of the Marketing Education Group Conference, Glasgow: The Department of Marketing, University of Strathclyde.

Cultureshop (2015). The rise of the micro-celebrity: Why brands should tap into this cultural phenomenon, https://medium.com/@QuantumSingapore/the-rise-ofthe-micro-celebrity-whybrands-should-tap-into-this-cultural-phenomenon, (Erişim Tarihi:17.02.2018).

Ecmercer (2015). Celebrity as a Practice, https://ecmercer.wordpress.com/author/ecmercer, (Erişim Tarihi:17.02.2018).

Erdogan, B. Z. (1999). Celebrity Endorsement: A Literature Review, Journal of Marketing Management, 15(4): 291-314.

Friedman, H. H., and Friedman, L. (1979). Endorser Effectiveness by Product Type Journal of Advertising Research, 19(5): 63-71.

Hearn A. (2008) Meat, mask, burden Probing the contours of the branded self. Journal of Consumer Culture 8(2):197-217. 
Instagram (2018). About us, https://www.Instagram.com/about/us/, (Erişim Tarihi:17.02.2018).

Kamins, A. (1990). An Investigation into the Match-Up-Hypothesis in Celebrity Advertising: When Beauty Be Only Skin Deep, Journal of Advertising, 19, No.1: pp.4-13.

Kamins, A. and Gupta, K. (1994). Congruence between Spokesperson and Product Type: A Matchup Hypothesis Perspective, Psychology and Marketing, 6:569-586.

Korotina, A., and Jargalsaikhan, T. (2016). Attitude towards Instagram micro-celebrities and their influence on consumers' purchasing decisions, Yayımlanmamış Yüksek Lisans Tezi, Jönköping Universitiy, 2016.

Lair, D., Sullivan, K. and Cheney, G. (2005). Marketization and the recasting of the professional self, Management Communication Quarterly 18(3):307-343.

Maddux, J., and Ronald W. R. (1980). Effects of source expertness, physical attractiveness, and supporting arguments on persuasion: A case of brains over beauty Journal of Personality and Social Psychology, 235-44.

Manikonda, L., Hu, Y. and Kambhampati, S. (2014). Analyzing User Activities, Demographics, Social Network Structure and User-Generated Content on Instagram, arXiv:1410.8099v1, 1- 5.

Marwick, A., and Boyd, D. (2011). To See and Be Seen: Celebrity Practice on Twitter. Convergence: The International Journal of Research into New Media Technologies, 17.

Marwick, A. (2015). You May Know Me from YouTube: (Micro-)Celebrity in Social Media, 333-350, Wiley Blackwell, Chichester, West Sussex, UK.

McCracken, G. (1989). Who is the Celebrity Endorser? Cultural Foundations of the Endorsement Process, The Journal of Consumer Research, 16(3):310-321.

Milgram, S. and Sabini, G. (1992). The Individual in a Social World: Essays and Experiments, New York: McGraw-Hill.

Misra, S., and Beatty, S. E. (1990). Celebrity spokesperson and brand congruence. An assessment of recal and affect, Journal of Business Research, 21(2):159-173.

Ohanian, R. (1991). The Impact of Celebrity Spokesperson's Perceived Image on Consumers' Intention to Purchase, Journal of Advertising Research, 31(1):46-52.

Raice, S. and Spencer, A. E. (2012). Insta-Rich: \$1 Billion for Instagram, Facebook Inks Its Biggest Deal Ever; Neutralizes Threat from a Hot Photo Start-Up, Wall Street Journal, 1.

Ruggless, R. (2013). Instant engagement: Margariteville marketing director discusses brand's Instagram strategy, Nation's Restaurant News, 47(19):92.

Senft T. (2008). Camgirls: Celebrity and Community in the Age of Social Networks, New York: Peter Lang.

Senft, T. M. (2013). Micro celebrity and the Branded Self., 346-354. A Companion to New Media Dynamics, Wiley-Blackwell.

Solomon, R., Askegaard, S. and Hogg, M. K. (2010). Consumer behavior: A European perspective, London: Prentice Hall.

Statista (2018). Countries with the most Instagram users as of January 2018,https://www.statista.com/statistics/578364/countries-with-most-Instagram-users/, (Erişim Tarihi:17.02.2018). 
$\mathrm{Su}$ A. (2017). Harnessing User-Generated Content Through Micro-Celebrity Endorsements,http://www.brandba.se/blog/harnessing-user-generated-content-through-microcelebrity-endorsements, (Erişim tarihi:17.02.2018).

Sunstrum, K. (2014). How Socail Media Affects Our Selfperception,https://psychcentral.com/blog/how-social-media-affects-our-self-perception, (Erişim Tarihi: 18.02.2018). 